\title{
A case study: the approach to the integrated and cooperative management of the water resources of the Maputo River Basin by Moçambique, Swaziland and South Africa
}

\author{
A. Tanner ${ }^{1}$, D. Mndzebele ${ }^{2} \&$ J. Ilomäki ${ }^{3}$ \\ ${ }^{I}$ Ninham Shand (Pty) Ltd, South Africa \\ ${ }^{2}$ Ministry of Natural Resources and Energy, Swaziland \\ ${ }^{3}$ Plancenter, Finland
}

\section{Abstract}

The Maputo River basin, has its headwaters in South Africa, covers a very significant part of Swaziland and flows into the Indian Ocean, south of Maputo, in Moçambique. The Governments of Moçambique, South Africa and Swaziland have been collaborating in the exchange of information, agreements on sharing of water, and joint studies since the early 1980s. The Tripartite Permanent Technical Committee (TPTC), responsible for providing advice to the three watercourse States, was established in 1983. In 2002 the Interim IncoMaputo Agreement was signed and identified that a "Comprehensive Agreement" is required in order for the states to collaborate in the equitable utilisation, management, development and protection of the shared watercourses.

This paper describes the approach followed and the "Joint Maputo River Basin Studies" (JMRBS), which is being undertaken to establish the Comprehensive Agreement. The "Scoping Study", completed in 2005, identified, collected and reviewed the available data for the catchment, and recommended the scope and level of detail for the Integrated Comprehensive Study of the Water Resources of the Maputo River Basin.

The Assessment of Water Resources and Related Social and Economic Aspects of the JMRBS are currently underway. The objectives are to develop and model the socio-economics and water resources of the catchment to enable Integrated Water Resources Management Scenarios (IWRMS) to be proposed. It will support the three countries in their efforts to reach agreement on: sustainable development, alignment of objectives, coordination of management, sharing of benefits of the resources, while respecting the sovereignty of each country regarding its policies and subjects.

Keywords: shared watercourses, integrated water resources management, water resources, water quality, environmental flow requirements, economics, hydrology management and development options. 


\section{The Maputo River Basin}

\subsection{Introduction}

The Tripartite Permanent Technical Committee (TPTC) was formally established on 17 February 1983 to inter alia make recommendations to the three countries, namely the Kingdom of Swaziland, the Republic of Moçambique, and the Republic of South Africa (RSA), on any measures to be undertaken to alleviate short-term problems regarding water shortages on all rivers of common interest during drought periods, on the division of water allocations, joint schemes, arrangements for the investigation of an access to common watersheds and joint water schemes and the required mechanism to co-ordinate and integrate the findings and plans of each country, including the appointment of Consultants as required.

It was clear that all three countries would benefit if, among other river basins, the water resources of the Maputo Basin were managed and developed in an integrated manner. Because the river basin extends across the political and administrative boundaries of Moçambique, Swaziland and South Africa, integrated management requires joint management.

\subsection{The interim agreement}

Various studies of the tributary catchments of the Maputo River have been conducted by the three countries and the information has formed the basis for an Interim Agreement (TPTC [1]) between the Republic of Moçambique, the Republic of South Africa and the Kingdom of Swaziland for co-operation on the protection and sustainable utilisation of the water resources of the Incomati and Maputo Watercourses. This Interim Agreement was formalised at the World Summit on Sustainable Development, which was held in August and September 2002 in Johannesburg.

However, a Comprehensive Agreement for the Use and Management of the Shared Waters of the Maputo Basin, the "Comprehensive Agreement" is required for the joint development and management of water resources by the three countries sharing the Maputo River Basin, in order to:

a) Enhance effective utilisation of the water resources of Maputo River;

b) Enhance sustainable economic development; and

c) Enhance the quality of the natural and social environments of the Maputo River Basin.

\subsection{Catchments and climate of the basin}

\subsubsection{Catchments}

The Maputo River Basin is located on the eastern side of the great continental divide. The basin is bordered by the Umbeluzi and Incomati Basins to the north, and the Umhlatuze coastal catchment to the south. The land area of the basin is about $30000 \mathrm{~km}^{2}$. The headwaters of the basin originate in South Africa, and 
the main tributaries flow through the southern half of Swaziland (Usuthu) and further south through South Africa (Phongolo), before joining on the South Africa / Moçambique border and flowing to the estuary in Maputo Bay (Figure 1).

The catchments of the Usuthu, Phongolo, and Ngwavuma Rivers, and the Maputo River downstream of the confluence of the Usuthu and Phongolo Rivers form the main sub-basins of the Maputo River Basin. The Usutho sub-basin is comprised of the Lusushwana, Mpuluzi, Usuthu (main stem), Ngwempisi and Mkhondvo catchments. The description of the Maputo River Basin in the Interim IncoMaputo Agreement is based on this basin subdivision.

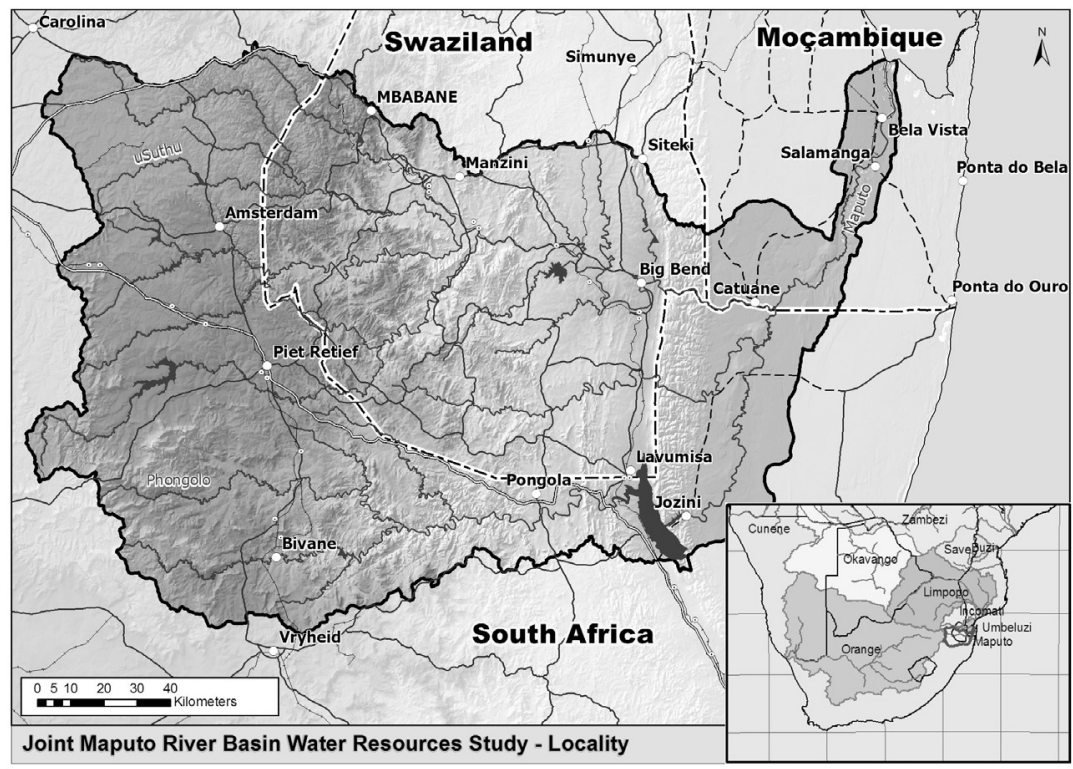

Figure 1: $\quad$ Locality map.

\subsubsection{Climate}

The climate of the Maputo River Basin is for the most part sub-tropical, but varies considerably from west to east. In the west, the climate of the interior plateau is temperate and sub-humid, the Lowveld is semi-arid and warm, and the Coastal Plain is warm to hot and humid. Along the south eastern coast of Africa, warm, moisture laden air of the subtropical eastern maritime system moves in from the sea. When the moist air is forced to rise above the land mass, cooling, condensation and rainfall occurs. The moist, warm air mass is unstable, and is the source of cyclonic activity. Very few cyclones make landfall, but when this happens, devastating floods result, such as those caused by cyclone Domoina in January 1984, Imboa in February 1984, and Eline in February 2000. The tropical cyclone season lasts from November to April, with activity peaking in January and February. 
Mean annual rainfall over the Maputo River Basin vary from about 500 $\mathrm{mm} /$ year in the Makhathini Flats on the Coastal Plain, to about $1400 \mathrm{~mm} /$ year in the vicinity of Mbabane on the Escarpment. Mean annual evaporation is lowest on the cooler interior plateau (1300 mm/year) and highest in the Coastal Plain, roughly inversely proportional to rainfall (MNRE [2]). Larger deficits in crop water requirements can therefore be expected in the eastern parts of the basin.

\section{The joint Maputo River Basin studies}

\subsection{Introduction}

The three countries agreed that a Joint Maputo River Basin Study (JMRBS) was required to provide the technical information about the resources and management of the river basin, and to identify alternative management and development options that would form the basis for the "Comprehensive Agreement".

The JMRBS comprises two phases:

$>$ A Scoping Study, which has been completed; and

$>$ Detailed studies.

The purpose of the Scoping Study was to establish the level and additional depth of study required and to develop a Study Plan for the detailed JMRBS studies required to inform the preparation of a Comprehensive Agreement.

\subsection{The scoping study}

The Scoping Study (MNRE [3]) commenced in November 2003 and was completed in the first quarter of 2005. It:

$>$ Established the issues to be addressed and deliverables required from the JMRBS so that it can provide a reliable source of information;

$>$ Defined the studies and level of investigations required for JMRBS;

$>$ Determined the data required to perform the JMRBS;

D Established the availability, quality, age, resolution, compatibility, homogeneity and adequacy of the data, and documented the status of the data;

$>$ Established the extent of the additional data which must be obtained, and the areas where the quality of the existing data must be improved;

$>$ Completed an initial stakeholder analysis, which included goals and objectives for Public Participation (PP), participation mandates, participation objectives, stakeholder profiles, and stakeholder organization and representation;

$>$ Held a series of stakeholder workshops, which explored, discussed and agreed Basin Study objectives, data sources and gaps; and

$>$ Developed relationships between relevant stakeholder groups.

\subsection{The comprehensive studies}

The objectives of the comprehensive JMRBS are to provide a detailed water resource assessment and recommended management and development options, 
as well as to propose suitable institutional and financial arrangements for the Maputo River Basin. These will be presented as an Integrated Water Resources Management Strategy (IWRMS).

The objective of the IWRMS is to provide a framework for the planning, development and management of a sustainable water resources system that can be used to fully contribute to the improvement of social and economic objectives of the three Basin States, while maintaining the water resources on a sustainable, high quality basis and avoiding degradation of the natural environment of the Maputo River Basin. The results of the JMRBS and the IWRMS will form the basis for the "Comprehensive Agreement".

During the Scoping Phase, the following study modules were identified for the second phase of the JMRBS.

\subsubsection{Study management}

The objective of the Study Management component of this assignment is to provide effective technical assistance to the TPTC Task Team with the procurement, management and co-ordination of the human, material and financial resources to achieve the objectives of the technical components of the JMRBS and, if required, to formulate technical sections of the Comprehensive Agreement for the Maputo River Basin.

\subsubsection{Public participation}

The objective of the Public Participation task is to ensure extensive consultation and participation throughout in the JMRBS, and to lay the foundation for ongoing and effective participation under the Comprehensive Agreement. Specific objectives are:

$>$ Creating awareness amongst stakeholders that will enable any of the Study Teams to interact effectively with a range of stakeholders.

$>$ Gaining an adequate and consistent understanding of stakeholders concerns and expectations.

$>$ Providing a legitimate and effective consultative base for cooperative basin management, this will increase the probability that the Comprehensive Agreement can be implemented with stakeholder buy-in.

$>$ Development of an environment of understanding of and support for the proposed "Comprehensive Agreement".

$>$ Consolidating existing Basin State capacity and processes for PP.

$>$ Security a resource and tool for participatory IWRM under the Comprehensive Agreement.

\subsubsection{Assessment of legal, institutional and financial arrangements}

The legal, institutional and financing consultancy will provide the legal, institutional and financial background to enable the Comprehensive Agreement to be implemented in practice. The aim of the Legal, Institutional and Financing consultancy is to recommend an institutional framework for cooperative 
management of the water resources. The proposals need to be practical and capable of implementation within the specific institutional and legal environments pertaining in each country.

\subsubsection{Environmental water requirements}

The Environmental Water Requirements (EWR) of the Maputo River and estuary are likely to be one of the most significant factors in determining the available yield and the potential for further water resource development. Furthermore, the EWR is essential to inform the management of the system in a sustainable manner and to predict the likely consequences of any change in flow regime. The objectives are to determine the EWRs for the ecological and social environments. This will include the temporal and spatial distribution of flows, as well as the water quality objectives for these environments.

The current differences between the countries with respect to the implementation and determination of EWRs and the methodologies used for assessing EWRs create challenges in terms of this assignment.

Acknowledging the holistic nature of the approach, it is important to recognize the potential for cumulative impacts on the Maputo Bay.

\subsubsection{Assessment of the water resources and related social and economic aspects of the maputo river basin}

This consultancy, now known as the "Joint Maputo River Basin Water Resources Study", (JMRBWRS) is currently underway and is discussed in Section 3.

\section{The joint Maputo River Basin water resources study}

In February 2006 the Government of Swaziland, acting on behalf of the European Commission and the three Countries, appointed consultants to undertake the JMRBWRS. The Study is being undertaken by Consortium consisting of Plancenter (Lead, Finland) and three South African Consulting Companies: Ninham Shand Consulting Services, Diversity and Transformation Solutions and Water for Africa. The end date of the Study is scheduled for July 2007. The objectives are to provide a detailed water resource assessment and recommended management and development options for the Maputo River Basin.

It is assessing the socio-economic and water resources information for the catchment to enable Integrated Water Resources Management Scenarios (IWRMS) for the optimum and sustainable utilisation of resources of the catchment to be prepared. Different development scenarios are being analysed with the associated environmental, socio and economic impacts and mitigation measures. It will enable decision-makers to reach agreement on the sharing of benefits of the resources of the catchment and move towards an integrated approach to the management of the system.

The initial findings are described in the following sections. 


\section{Water use and water resources}

\subsection{Water use}

The major water users in the Maputo Basin are irrigation, afforestation and transfers from the Upper Usuthu catchment to the Vaal and Olifants catchments.

Irrigated agriculture and commercial forestry the largest water users in the basin, have expanded by about $1.4 \%$ and $0.6 \%$ per annum on average over the past 25 years, and now cover about 55 000ha and 367 000ha respectively. Irrigated agriculture in the Moçambique portion of the basin has declined from about 3800 ha in 1981 to about 200 ha in 2005 .

There are five areas in the basin where formal irrigation schemes have been established for smallholder farming, totalling about 16000 ha in Swaziland (after completion of the LUSIP scheme), 4000 ha in South Africa, and about 180 ha near Salamanga in Moçambique. Plans have been put forward to expand most of the smallholder schemes.

There are large areas of dry land subsistence farming in the lower Usuthu and Ngwavuma catchments, and smaller areas in the Ngwempisi, Lusushwana and Mkhondvo catchments. Individual land holdings are generally less than 2 ha in size. Subsistence farming areas in the lower Phongolo and Maputo catchments are mostly located in the floodplain, and are usually irrigated with furrows.

Available data indicate that at least 24000 ha (equivalent area at $100 \%$ density) of the Maputo River Basin land area has been invaded by alien plant species. Compared to the rest of the basin, the Maputo catchment in Moçambique is relatively free of invasive alien plants (MNRE [4]).

\subsection{Groundwater aquifers}

The eastern half of the Coastal Plain is situated on the largest primary aquifer in Southern Africa. Along the Maputo River, the unconsolidated alluvial terraces have some of the highest yields in the basin (>5 1/s) (MNRE [5]). It is very likely that there is significant interaction between the porous alluvial aquifers and the river channel, implying that the groundwater and surface water in these areas should be managed as one resource. Aquifer yields decline in the semiconsolidated Cretaceous rocks in the western half of the Coastal Plain. There is a small, but high yielding $(2-5 \mathrm{l} / \mathrm{s})$ karst aquifer located upstream of the confluence of the Phongolo and Ngwavuma Rivers, between the two rivers. Aquifers in the Lebombo Range and Lowveld have some of the lowest yields in the basin $(0.1-0.5 \mathrm{l} / \mathrm{s})$. The Lebombo Rhyolites are generally fresh, hard, and non-water bearing. Local fracturing of the massive basalt rocks do however provide water-bearing zones with recorded blown yields of up to $7 \mathrm{l} / \mathrm{s}$. Metamorphic units (mainly gneisses) are widely distributed in the Escarpment Region. The gneisses are not significantly weathered, and are therefore not easily infiltrated. The granitic areas in the Middleveld, Escarpment and Interior Plateau regions are favoured targets for groundwater exploration. Aquifers are moderately productive, with yields of about 0.5 to $21 / \mathrm{s}$. There are also contact springs in the area. 


\subsection{Current surface water resources}

\subsubsection{Quantity}

The Maputo River Basin comprise of eight catchments and covers about $29970 \mathrm{~km}^{2}$. The natural mean annual runoff (MAR) amounts to about 3770 $\mathrm{Mm}^{3} / \mathrm{a}$, of which about $58 \%$ is from South Africa, $40 \%$ from Swaziland and 2\% from Moçambique (MNRE [6]).

It is estimated that the development in the Maputo Basin has reduced the natural MAR by between $25 \%$ and $30 \%$, while the runoff in the Usuthu and Phongolo Rivers upstream of Moçambique have been reduced by about 25 and $35 \%$, respectively.

\subsubsection{Quality}

In terms of its fitness for use, potential problems relate to the build-up of salts, potential nutrient enrichment problems, and potential problems related to acid mine drainage or acid rain deposition (MNRE [7]).

\subsection{Water resources infrastructure}

Most of the water infrastructure in the Maputo River Basin has been developed during the past 50 years. There are two large schemes that transfer water from the upper Mkhondvo and Ngwempisi catchments to the Vaal system for power generation; regional irrigation schemes in the lower Usuthu, Ngwavuma and Phongolo River catchments; and smaller local schemes for water supply to the towns and rural settlements in the basin (MNRE [2]).

\subsection{Water balance assessments}

An initial water balance has been completed to identify sub-systems with development potential, as well as areas where deficits are imminent. The water balance calculation was performed by Water Management sub catchment. Analysis was for a present day (2005) scenario.

The water balance exercise found that there is surplus water available in the Upper Phongolo catchment, as well as from the Bivane and Pongolapoort Dams. There is a shortfall at the dams in the Upper and middle Usuthu catchments, which is mainly as a result of the transfers, combined with the potential environmental requirements for the areas downstream of these dams (MNRE [8]).

\section{Future scenarios}

\subsection{Introduction}

An assessment of local and regional spatial development plans, the probable EWRs, the initial water balance, projected future water use as well as management and infrastructure development options, shows that a likely short to medium term scenario could look as follows (MNRE [2]): 
Swaziland:

$>$ Significant expansion (+-14 $000 \mathrm{ha}$ ) of smallholder irrigation in the Lusushwana, Mkhondvo, lower Usuthu and Ngwavuma catchments;

$>$ Limited expansion of commercial plantations in the escarpment region;

$>$ Development of small dams and groundwater resources to improve assurance of existing supplies;

$>$ Improved efficiency of water use in the irrigation sector;

$>$ Commencement of a programme to eradicate invasive alien plants;

$>$ Development of one or two major dams to support the increased areas of irrigation and further improve assurance of supply, while meting the EWR.

Moçambique:

$>$ Expansion of smallholder and commercial irrigation, mainly through the rehabilitation of disused irrigation schemes in the Salamanga and Catuane area;

$>$ Some expansion of commercial plantations (outside the boundaries of the Maputo water course) due to renewed foreign investment in this sector.

$>$ Possible water transfers for urban use (Ponta Dobela and/or Maputo)

$>$ Development of one or possibly two off channel storage dams to improve the assurance of supply to existing and future users while meeting the EWR.

South Africa:

$>$ Very limited expansion of irrigated areas, almost exclusively to benefit rural poor, and making use of existing unused water allocations;

$>$ No significant expansion of commercial plantations;

$>$ Some expansion of dry land (sugar cane) agriculture;

$>$ Limited development of small dams and groundwater resources to improve assurance of supply;

$>$ Increased municipal (domestic) water use as water and sanitation service backlogs are gradually reduced. Improved efficiency of water use in the irrigation sector;

$>$ Improved efficiency of water use in the irrigation sector;

$>$ Continued progress with eradication of invasive alien plants; Maintenance of existing inter-basin transfers

$>$ Development of one or two major dams to maintain the assurance of supply for existing transfers and water users while meeting the EWR.

\section{Conclusions}

The Study is now at the point where all the key information and basic analyses have been completed. The development of the IWRMS for consideration by the three countries is in progress. The challenges are; improve the confidence in the water resource assessment through further monitoring and calibrations, to improve the confidence in the EWRs through more detailed studies, improve the 
efficiency of water use and to improve the socio economic benefits of water used in the catchment.

\section{Acknowledgements}

The authors gratefully acknowledge the study funding provided by the EU, the support of the officials from all their countries and the contributions of all members of the study team to the ongoing studies.

\section{References}

[1] TPTC - Tripartite Technical Committee, for Moçambique, South Africa and Swaziland, Interim Inco Maputo Agreement, 2002.

[2] MNRE - Ministry of Natural Resources and Energy, Swaziland, representing DNA of Moçambique and DWAF of South Africa, Report on Basin Characteristics, Land Use and Water Resources Infrastructure, 2007.

[3] MNRE - Ministry of Natural Resources and Energy, Swaziland, representing DNA of Moçambique and DWAF of South Africa, Report on Integrated Scoping Phase of the Water Resources of the Maputo River Basin, 2007.

[4] MNRE - Ministry of Natural Resources and Energy, Swaziland, representing DNA of Moçambique and DWAF of South Africa, Report on Baseline Surface Water Resource Availability, 2007.

[5] MNRE - Ministry of Natural Resources and Energy, Swaziland, representing DNA of Moçambique and DWAF of South Africa, Report on Ground Water Resources, 2007.

[6] MNRE - Ministry of Natural Resources and Energy, Swaziland, representing DNA of Moçambique and DWAF of South Africa, Report on Present Water Resource Availability, 2007.

[7] MNRE - Ministry of Natural Resources and Energy, Swaziland, representing DNA of Moçambique and DWAF of South Africa, Report on Surface Water Quality Assessment, 2007.

[8] MNRE - Ministry of Natural Resources and Energy, Swaziland, representing DNA of Moçambique and DWAF of South Africa, Report on Water Requirements and Assessment Water Resource Availability Water Balance, 2007. 